\title{
The Effect of Dividend Policy on the Market Value of the Jordanian Commercial and Islamic Banks Listed on the Amman Stock Exchange
}

\author{
Dr. Naseem Abu Roman ${ }^{1}$ \\ ${ }^{1}$ the World Islamic Sciences and Education University WISE, Jordan \\ Correspondence: Dr. Naseem Abu Roman, the World Islamic Sciences and Education University WISE, Jordan. \\ E-mail: naseemm55@yahoo.com
}

Received: July 2, 2019

Accepted: July 22, 2019

Online Published: July 25, 2019

doi:10.5539/mas.v13n8p40

URL: https://doi.org/10.5539/mas.v13n8p40

\begin{abstract}
This study aims at examining the effect of Dividend Policy on the market value of Jordanian commercial and Islamic banks. The study population consists of all Jordanian banks listed on the Amman Stock Exchange during the period from 2008 - 2018. Data were collected from the annual reports of the sample banks. After the data collection, they were analyzed using descriptive analysis, correlation analysis, and multiple regression analysis.

The results showed a statistically significant impact of dividend policy, this result indicates that there is an impact of the dividend policy on the market value of Jordanian commercial and Islamic banks listed on the ASE during the period 2008-2018. The results also showed a difference between the companies in terms of dividend policy followed, in addition, asymmetry in the Dividend Policy in banks during the study period. The study recommended a number of recommendations, including that manager of firms, should develop effective dividend payout policies to ensure that their firms pay out dividends to enhance the value of their companies and plan an efficient and reliable dividend policy, to suit the wishes of investors, and to engage stakeholders in a dialogue on dividend policy.
\end{abstract}

Keywords: dividend policy, market value, Jordanian commercial and Islamic banks

\section{Introduction}

The maximization of shareholder wealth is one of the most important objectives of companies by maximizing their value. Consequently, there are many decisions that can affect the company's value, such as financing decisions that determine whether they should rely on external financing such as debt, By using retained earnings instead of borrowing, and thus the trade-off between the distribution of profits or the holding of owners in order to reinvest them for expansion and growth (Said Omar \& Echchabi, 2019).

Dividends not only provide tangible and tangible evidence of the company's profitability and ability to finance itself but also provide real evidence of the company's ability to get cash from its operational activities. Adesola and Okwon (2009). That the company will resort to another source of cash such as issuing new shares or borrowing to finance new projects. (Sindhu, 2014).

The examination of the relationship between the dividend policy and the concentration of ownership with the performance of Jordanian financial companies is itself important for the current study because there are differences between the environment in which most of the previous studies and the working environment of Jordanian financial companies in terms of market efficiency and the size of information available to researchers, , And the size of the financial and accounting disclosure in the annual reports. This study will also attempt to cover the last ten years to test the relationship between the dividend policy and the performance of Jordanian financial companies.

The capital market in Jordan is a developing market characterized by limited competition, low liquidity and high rate of return and risk compared to the markets of developed countries. Most investors who lose money on stock exchanges are usually small investors because they may not be stock market professionals. Or because they lack the ability to determine the factors influencing stock prices, especially with respect to financial structure and cash dividends, and may not have the ability to identify which stocks to buy or sell, so knowing the impact of dividend policy and financial structure on the stock market price can help investors to understand the nature of these stocks and the possibility of avoiding the loss of equity. Hence the problem of this study in identifying the impact of dividend policy on the market value of Jordanian commercial and Islamic banks. 


\section{Literature Review}

\subsection{Theoretical Background}

The Bank's financial decisions are classified into two main categories: investment decisions and financing decisions (Baker \& Powell, 1999). Investment decisions pertain to the type and quantity of assets that you wish to maintain. Financing decisions involve securing funds to finance these assets, (Banerjee et al., 2007). Dividend policy decisions can be considered as financing decisions as they affect the amount of dividends distributed to shareholders and the amount of retained earnings for reinvestment (Biza-Khupe \& Themba, 2016).

Dividend policy is one of the most challenging issues in the modern financial economy. The best distribution policy requires balancing current distributions and future profits so that they reflect positively on share price, meet owners' needs or send a market signal about a particular situation. (Chumari, 2014). Emeni and Ogbulu (2015) considers dividend policy to be the basis and principles for dividing profits into a portion that is distributed to shareholders and a portion that is held for reinvestment. Determining the amount of profits to be paid will affect the wealth of shareholders and the ability of the bank to retain profits to invest in available investment opportunities. Therefore, dividend and financing decisions are interrelated and cannot be separated (Banerjee, et al., 2007). For example, if the bank decides to distribute dividends to shareholders, it means that the profits available to invest in profitable projects are low, leading to a trend towards external financing, so it is not surprising to see some managers looking at cash dividends as a factor that would effect On shareholder wealth and bank value (Baker \& Powell, 1999).

According to the Bird-In-Hand Theory, cash dividends are relevant and affect the market value of a share. Investors value dividends more than capital gains when making investment decisions. Current cash dividends are relatively assured compared to future capital gains, therefore, a bird in the hand (dividend) is, better than a group of birds on the tree (capital gains). According to this theory, investors prefer to get a certain amount of income now instead of waiting for a higher amount of uncertain income in the future (Al-Malkawi, 2007), and the risk premium resulting from uncertainty leads to an increase in the required return, Share price (Abdella, et al., 2016). According to the signaling theory of reference, dividend policy can refer to hidden information about the bank based on its managers' procedures towards maximizing wealth for shareholders. The theory suggests that any changes in cash dividends will prompt investors to think about the future value of the bank (Ali, 2010).

The agency's theory plays an important role in financing decisions because of problems between debtors and shareholders (Deepte \& Roshan 2009). The agency's theory suggests that managers prefer to have a high level of cash flow even if there is no profitable investment opportunity they can use the funds to achieve their own benefits more than strengthening or increasing the value of banks (Abdella, et al., 2016). The Agency's theory assumes that capital structure decisions should aim at reducing Agency-related costs by reducing financing from owners in the capital structure (Afza \& Mirza, 2010). This is done through increased debt financing and thereby increasing the Bank's market value as well as reducing conflicts which may exist between bank managers and shareholders (Wang, 2010).

\subsection{Empirical Literature}

Many studies have sought to determine the impact of dividend policy on companies and their financial performance and on the reactions of the market. The study of Friend and Puckett (1964) was one of the first studies to examine the impact of dividend policy on stock prices, where it was found that the dividends affect positively on the share price. In contrast, Baskin (1989) found an inverse relationship between dividend policy and stock price volatility in the United States. With regard to recent studies, Murekefu and Ouma (2013) showed that dividend policy is an important and influential factor in the company's performance, Uwuigbe et al. (2012) also discovered that there is a positive relationship between the performance of the company and dividend policy, which improves the value of market shares and thus affect the market values of companies. Ajanthan (2013) also showed that there is a positive relationship between the dividend policy and profitability of the company in Sri Lanka. Luvembe et al. (2014) found that there is an impact for dividend policy on the market value of commercial banks in Nairobi Stock Exchange, noting that investor decisions in financial markets are heavily dependent on both the financial structure and the dividend policy pursued by banks.

Chenchehene and Mensah (2015) also discussed the impact of the dividend policy on shareholders wealth in the UK. The shareholder's wealth was measured using the market value to book value of the share price. The study found that dividend policy affects the shareholder's wealth by affecting the share price. SijolNur and Abdul Basit (2016) found that the dividend policy did not have a consistent pattern of influencing the financial performance of companies in the US, nor did the study find a clear relationship between the value of the market share and the 
dividend policy of companies listed in the sample. Adesina et al., (2017) showed that there is a significant positive correlation between dividend policy and the market price of bank shares in Nigeria.

Based on a review of previous literature, the following hypotheses can be formulated:

Ho: There is no statistically significant effect of dividend policy on the market value of Jordanian commercial and Islamic banks listed on the ASE.

This main hypothesis is divided into two sub-hypotheses:

Ho.1: There is no statistically significant effect of dividend policy on the market value of Jordanian commercial banks listed on the ASE.

Ho.2: There is no statistically significant effect of dividend policy on the market value of Jordanian Islamic banks listed on the ASE.

\section{Study Methodology}

\subsection{Population and Sample of Study}

The study population consists of all (15) Jordanian banks listed on the Amman Stock Exchange during the period from $(2008-2018)$. The study will be based on a comprehensive survey system. The sample will include the entire community.

\subsection{Sources of Data Collection}

The researcher relied on secondary data by reviewing the books and studies related to the subject of this study. For the purpose of the analysis, reference was made to the websites of the banks included in the study sample and the website of the Amman Stock Exchange (www.ase.jo) in order to obtain the financial statements of banks and collect the necessary data.

\subsection{Measurement of Study Variables}

Dependent variable: Market Value (MV): The researcher measured the market value by market value of the total outstanding shares of the Bank as follows:

Market value $(\mathrm{MV})=$ Number of shares traded $\times$ Market price at the end of the year.

Independent variables: Dividend Policy (DIV): measured by dividends divided by earnings per share as follows:

Dividend Policy $(\mathrm{DIV})=$ dividends / Earning Per Share.

\section{Control variables:}

Bank Size (SIZE): measured by the natural logarithm of total assets at the end of the year.

Debt Ratio (DEBT): measured by total liabilities to total assets at the end of the year.

\subsection{Model}

The standard model below will be adopted to test the hypotheses of the study:

$\mathbf{M V}_{\text {it }}=\beta 0+\beta 1$ DIV $_{\text {it }}+\beta 2$ SIZE $_{\text {it }}+\beta 4$ DEBT $_{\text {it }}+\varepsilon_{\text {it }}$

Where:

MV ${ }_{\text {it }}$ : Number of shares traded for bank (i) at the end of the year ( $\left.t\right) \times$ Market price for bank (i) at the end of the year.

DIV $_{\text {it: }}$ dividends for bank (i) at the end of the year ( $t$ ) / Earning per Share for bank (i) at the end of the year ( $t$ ).

SIZE $_{i t}$ : the natural logarithm of total assets for bank (i) at the end of the year ( $(t)$.

DEBT $_{\text {it: }}$ : total liabilities bank (i) at the end of the year ( $t$ ) / total assets bank (i) at the end of the year ( $t$ ).

$\boldsymbol{\varepsilon}_{\mathrm{it}}$ : Random error.

\section{Results}

\subsection{Descriptive Statistics of the Study Variables}

The following table represents descriptive measures for model variable according to Islamic and commercial banks. 
Table 1. Descriptive statistics

\begin{tabular}{llllll}
\hline Variables & Bank Type & Mean & Stdev. & Max & Min \\
\hline \multirow{3}{*}{ MV } & Islamic & 19.155 & 0.810 & 20.303 & 18.165 \\
\cline { 2 - 6 } & Commercial & 19.485 & 1.131 & 22.397 & 17.593 \\
\cline { 2 - 6 } DIV & Whole Sample & 19.441 & 1.097 & 22.397 & 17.593 \\
\hline \multirow{3}{*}{ SIZE } & Islamic & 0.081 & 0.071 & 0.150 & 0.000 \\
\cline { 2 - 6 } & Commercial & 0.118 & 0.092 & 0.400 & 0.000 \\
\cline { 2 - 6 } & Whole Sample & 0.113 & 0.090 & 0.400 & 0.000 \\
\hline \multirow{3}{*}{ DEBT } & Islamic & 20.728 & 1.020 & 22.134 & 18.747 \\
\cline { 2 - 6 } & Commercial & 21.427 & 1.056 & 24.313 & 19.521 \\
\cline { 2 - 6 } & Whole Sample & 21.334 & 1.074 & 24.313 & 18.747 \\
\cline { 2 - 6 } & Islamic & 0.839 & 0.103 & 0.929 & 0.590 \\
\cline { 2 - 6 } & Commercial & 0.856 & 0.025 & 0.909 & 0.780 \\
\hline
\end{tabular}

Table 1. Shows that the mean of all variables' values of commercial banks exceed the values of Islamic banks. But when tracing the max values of both types of banks during the period, we can notice that the debt ratio for Islamic banks exceeded sometimes the values of commercial banks. Moreover, the minimum values of banks size indicate that Islamic banks are not the smallest banks in the Jordanian banking sector. For market values, we can conclude there is some similarity between both types.

\subsection{Estimate the Model}

The study adopts the econometric analysis using panel data that combines time-series and cross-sectional data.

To investigate the effect in study models, the study depended on the model related for panel data:

1- Pooled Regression Model (PRM)

2- $\quad$ Fixed Effect Model (FEM)

3- Random Effect Model (REM)

Lagrange Multiplier was applied to select the effective model from (PRM) and (REM), while Hausman test was applied to decide the appropriate model from (FEM) and (REM).

Table 2. Lagrange Multiplier test and Hausman tests results

\begin{tabular}{llllll}
\hline \multirow{2}{*}{ Research Model } & \multicolumn{2}{l}{ Lagrange Multiplier } & \multicolumn{2}{l}{ Hausmann } & \multirow{2}{*}{ Appropriate Model } \\
\cline { 2 - 5 } & $\mathbf{C h i}^{\mathbf{2}}$ & Sig. & $\mathbf{C h i}^{\mathbf{2}}$ & Sig. & \\
\hline Islamic & 0.859 & 0.354 & - & - & PRM \\
\hline Commercial & 69.823 & 0.000 & 27.986 & 0.000 & FEM \\
\hline Whole Sample & 48.875 & 0.000 & 52.998 & 0.000 & FEM
\end{tabular}

Lagrange Multiplier test, to select an appropriate model (PRM) and (REM)

H0: PRM is more consistent than REM

Hausman test, to select an appropriate model (FEM) and (REM)

H0: REM is more consistent than FEM

According to result Lagrange multiplier test and Haussmann test, fixed effects model (FEM) is the most appropriate method for estimation model parameters of both main and second sub-hypothesis. With FEM slope of regression is constant across all cross-sections. Though time effect is not significant, whereas there are significant differences between cross-sections, in the same time, cross-section coefficients do not change during time. To represent cross-sectional effect, dummy variables are used. Also, result indicate that pooled regression model is the most appropriate for first sub-hypothesis. 


\subsection{Hypotheses Testing}

4.3.1 Result of Main Hypothesis Testing

Table 3. Fixed Effect Model for H0

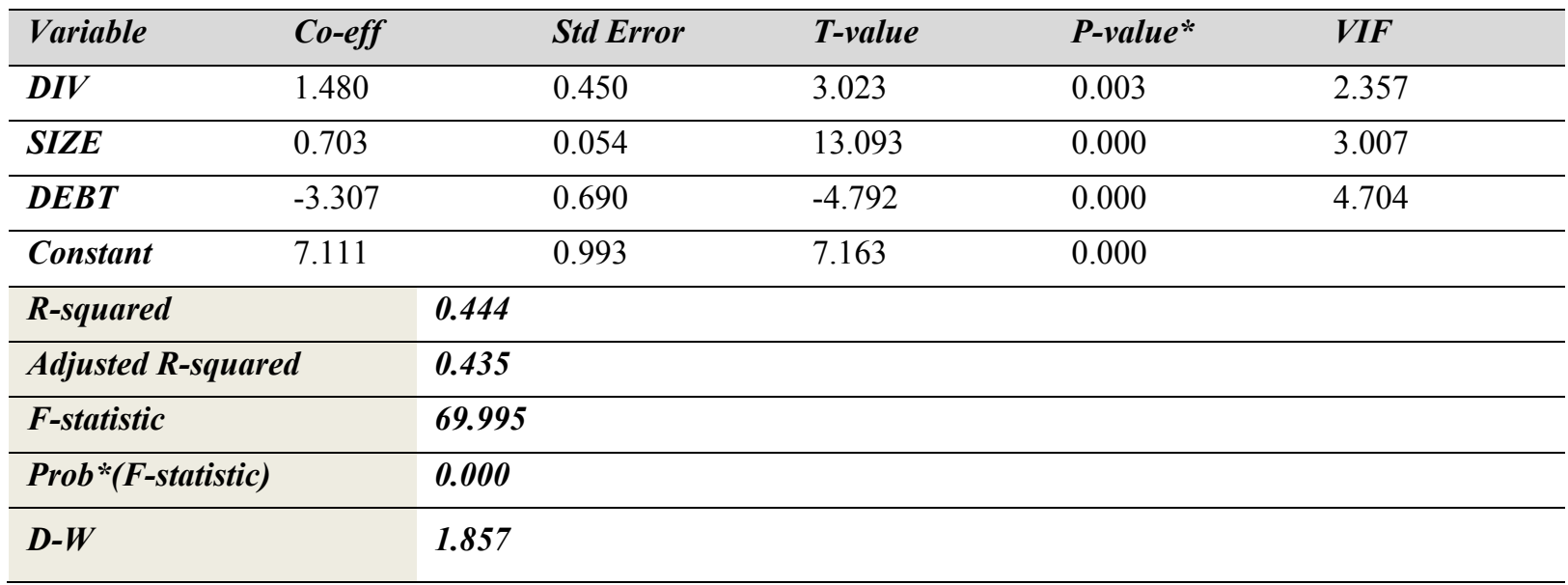

*Significant at 0.05 level.

The above table reports that $\mathrm{R}$ Square, the coefficient of determination equal to (0.444), which means that about $(44.4 \%)$ of the variation in market value of Jordanian banks (MV) is explained by the model. The significance value of the $F$ statistic $(F=69.995)$ is (Prob $F=0.000)$ less than 0.05 , which means that the effect of independent variables aggregated is significant.

Moreover, the coefficients of the regression states that (DIV) has a significant positive effect on MV, where coefficient value equals $(1.480)$ is significant with $(\mathrm{t}=3.023)$ and $(\mathrm{P}$-value $=0.003)$ less than 0.05 , (SIZE) has a significant positive effect, where coefficient value equals $(0.703)$ is significant with $(\mathrm{t}=13.093)$ and (P-value $=0.000)$. (DEBT) has a negative significant effect, where coefficient value equals $(-3.307)$ is significant with $(\mathrm{t}=$ $-4.792)$ and $(\mathrm{P}$-value $=0.000)$.

Moreover, $(\mathrm{D}-\mathrm{W}=1.857)$ indicates there is no serial correlation, where Durbin-Watson value nearby (2) indicate there is no serial correlation between error terms.

This result indicates the impact of the dividend policy on the market value of Jordanian commercial and Islamic banks listed on the Amman Stock Exchange during the period 2008-2018. This finding is consistent with what Adesina et al. (2017). This result can be explained by the Signaling Theory, which assumes that the gap between what managers know about the bank and what investors know can be bridged by the use of dividends. The Bank's dividend policy can transfer information to the market Future investors. In other words, earnings can be a sign of the bank's future earnings and thus affect the volume of demand for its shares and thus its market value

4.3.2 Result of First Sub-Hypothesis Testing

Table 4. Pooled Regression Model for H01

\begin{tabular}{|c|c|c|c|c|c|}
\hline Variable & Co-eff & Std Error & $T$-value & P-value* & $V I F$ \\
\hline DIV & 9.351 & 2.366 & 3.952 & 0.002 & 1.873 \\
\hline SIZE & 0.081 & 0.234 & 0.347 & 0.735 & 2.004 \\
\hline DEBT & -0.030 & 1.823 & -0.016 & 0.987 & 3.171 \\
\hline Constant & 16.719 & 3.775 & 4.429 & 0.000 & \\
\hline R-squared & & & & & \\
\hline Adjusted R-squared & & & & & \\
\hline F-statistic & & & & & \\
\hline Prob $*(F$-statistic $)$ & & & & & \\
\hline$D-W$ & & & & & \\
\hline
\end{tabular}

\footnotetext{
*Significant at 0.05 level.
} 
The above table reports that $\mathrm{R}$ Square, the coefficient of determination equal to $(0.258)$, which means that about $(25.8 \%)$ of the variation in market value of Jordanian Islamic banks (MV) is explained by the model. The significance value of the $\mathrm{F}$ statistic $(\mathrm{F}=24.140)$ is (Prob $\mathrm{F}=0.000)$ less than 0.05 , which means that the effect of independent variables aggregated is significant.

Moreover, the coefficients of the regression states that (DIV) has a significant positive effect on MV, where coefficient value equals $(9.351)$ is significant with $(\mathrm{t}=3.652)$ and $(\mathrm{P}-\mathrm{value}=0.002)$ less than 0.05 , (SIZE) has no significant effect, where coefficient value equals $(0.081)$ is not significant with $(\mathrm{t}=0.347)$ and $(\mathrm{P}$-value $=0.735)$. (DEBT) has no significant effect, where coefficient value equals $(-0.030)$ is not significant with $(\mathrm{t}=--0.018)$ and $(\mathrm{P}$-value $=0.987)$.

Moreover, $(\mathrm{D}-\mathrm{W}=1.796)$ indicates there is no serial correlation, where Durbin-Watson value nearby (2) indicate there is no serial correlation between error terms.

This result indicates the impact of the dividend policy on the market value of Jordanian commercial banks listed on the Amman Stock Exchange during the period 2008-2018. This finding is consistent with what Adesina et al. (2017). This result can be explained by the Signaling Theory, Which assumes that dividends provide an indication of the financial markets about the performance of banks and their management efficiency, and thus they are an indicator of their ability to achieve their goals and maximize their wealth. Hence, they play a central role in the level of demand for bank shares and thus affect the values of market shares, and therefore the market values of banks.

\subsubsection{Result of Second Sub-Hypothesis Testing}

Table 5. Pooled Regression Model for H02

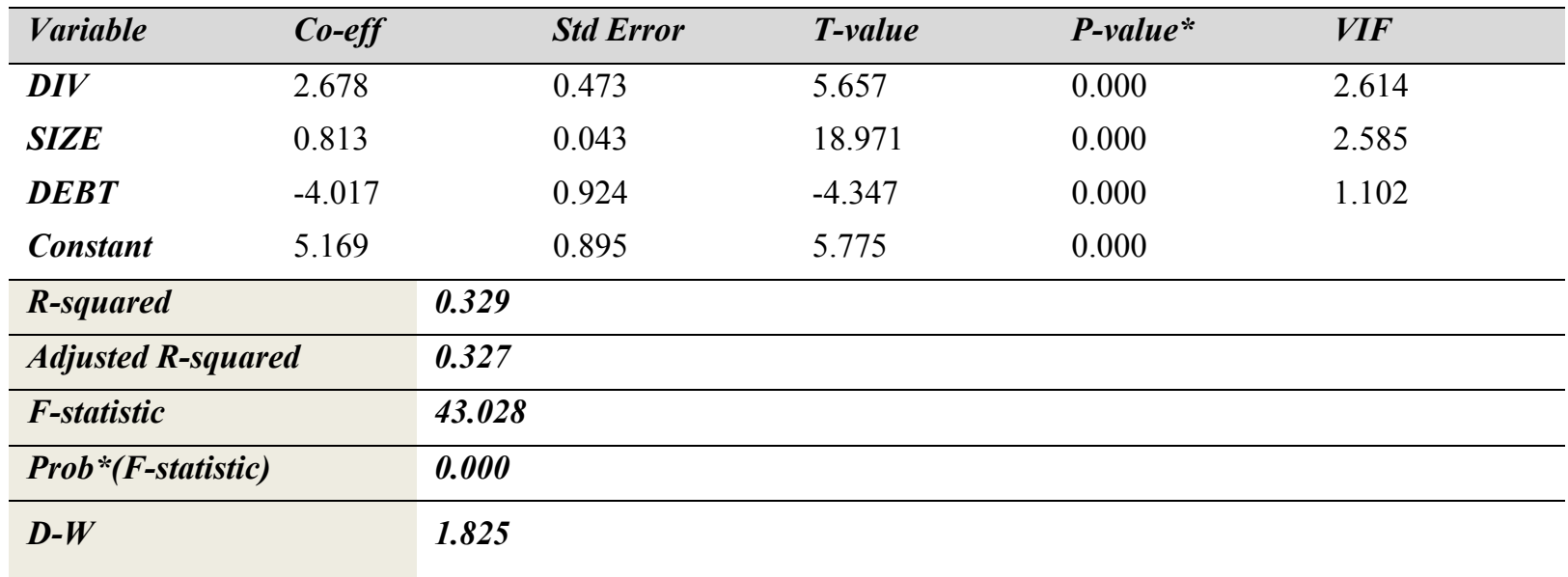

*Significant at 0.05 level.

The above table reports that R Square, the coefficient of determination equal to (0.329), which means that about $(32.9 \%)$ of the variation in market value of Jordanian Commercial banks (MV) is explained by the model. The significance value of the $F$ statistic $(F=437.028)$ is (Prob $F=0.000)$ less than 0.05 , which means that the effect of independent variables aggregated is significant.

Moreover, the coefficients of the regression states that (DIV) has a significant positive effect on MV, where coefficient value equals $(2.678)$ is significant with $(\mathrm{t}=5.657)$ and (P-value $=0.000)$ less than 0.05 , (SIZE) has a significant positive effect, where coefficient value equals $(0.813)$ is significant with $(\mathrm{t}=18.971)$ and $(\mathrm{P}$-value $=0.000)$. (DEBT) has a negative significant effect, where coefficient value equals $(-4.017)$ is significant with $(\mathrm{t}=$ -4.347) and (P-value $=0.000)$.

Moreover, $(\mathrm{D}-\mathrm{W}=1.825)$ indicates there is no serial correlation, where Durbin-Watson value nearby (2) indicate there is no serial correlation between error terms.

This result indicates the impact of the dividend policy on the market value of Jordanian Islamic banks listed on the Amman Stock Exchange during the period 2008-2018. This result can indicate that dividends give a signal about the ability of banks to continue to make profits and maximize shareholders' wealth. It also indicates the efficiency of the bank's management and its ability to maintain investor funds. Investors 'views on Islamic banks' shares are also no different from those of commercial banks. 


\section{Conclusion and Recommendations}

This study aimed at identifying the impact of dividend policy on the market value of Jordanian commercial and Islamic banks. The study population consists of all Jordanian banks listed on the Amman Stock Exchange during the period from $2008-2018$. The study is based on a comprehensive survey system. The sample includes the entire community.

This result indicates that there is an impact of the dividend policy on the market value of Jordanian commercial and Islamic banks listed on the ASE during the period 2010-2017. Which indicates the earnings can be a sign of the bank's future earnings and thus affect the volume of demand for its shares and thus its market value. And there is an impact of the dividend policy on the market value of Jordanian commercial banks listed on the Amman Stock Exchange during the period 2008-2018. This result indicates that dividends provide an indication of the financial markets about the performance of banks and their management efficiency, and therefore the market values of banks. And there is an impact of the dividend policy on the market value of Jordanian Islamic banks listed on the ASE during the period 2010-2017. Which indicates that the Investors 'views on Islamic banks' shares are also no different from those of commercial banks.

Based on these findings, the study recommends the need to involve the management of banks to the shareholders in the dialogue on dividends, in order to clarify the role of cash dividends in improving the performance of banks and thus maximize their wealth in the future. As well as the need for the managers of banks listed on the stock exchange to develop a policy of cash dividends are effective and appropriate to the needs of investors, as this will affect the values of shares market and maximize the benefit of investors shares. As cash dividend distribution plays a significant role in influencing stock prices and market values.

\section{Future Studies and Research}

This study does not address many of the variables associated with cash dividends and financial structure. Therefore, this study recommends a series of future studies that may contribute to understanding the relationship between cash dividends, financial structure and market values of banks. The announcement of cash dividends and their impact on the reactions of the financial markets, as well as the impact of non-cash distributions, such as dividends.

The study reviewed only a sample of financial companies listed on the stock exchange, where the banking sector was studied only, and did not cover companies in other sectors or companies not listed on the stock exchange. Therefore, the study recommends conducting further studies to include companies in the industrial sector, insurance and other sectors, To private and small companies in order to be able to generalize the results of the effects of cash dividends and the financial structure on the market values of companies.

\section{References}

Abdella, A., Manual V. \& Kannan G. (2016). A Study on the Determinants of Dividend Policies of Commercial Banks in Saudi Arabia. Imperial Journal of Interdisciplinary Research (IJIR), 2(9), 1064-1073. [Online] Available: http://www.onlinejournal.in

Adesina, K., Uwuigbe, U., Uwuigbe, O., Asiriuwa, O., Oriabe S. (2017). Dividend Policy and Share Price Valuation in Nigerian Banks. Euro Economica, Macroeconomics and monetary economics, 1(36), 185-195.

Adesola, W. \& Okwong, A. (2009), An empirical study of dividend policy of quoted companies in Nigeria. Global Journal of Social Sciences, 8(1), 85-101. https://doi.org/10.4314/gjss.v8i1.48907

Afza, T., \& Mirza, H. (2010). Ownership structure and cash flows as determinants of corporate dividend policy in Pakistan. International Business Research, 3(3), 210-221. https://doi.org/10.5539/ibr.v3n3p210

Ajanthan, A. (2013). The Relationship between Dividend Payout and Firm Profitability: A Study of Listed Hotels and Restaurant Companies in Sri Lanka. International Journal of Scientific and Research Publications, 3(6), 251-260.

Ali, M. (2010). Effect of dividend on stock price in emerging stock market: a study on the listed private commercial banks in DSE. International Journal of Economics and Finance, 2(4), 52-64. https://doi.org/10.5539/ijef.v2n4p52

Al-Malkawi, H. (2007). Determinants of corporate dividend policy in Jordan: an application of the Tobit model. Journal of Applied Accounting Research, 23, 44-70. https://doi.org/10.1108/10264116200700007

Baker, H. Kent, \& Powell, G. E. (1999). How Corporate Managers View Dividend Policy. Quarterly Journal of Business and Economics, 38(2), 17-35. https://www.jstor.org/stable/40473257 
Banerjee, S., Gatchev, V. A. \& Spindr, P. A. (2007). Stock Market Liquidity and Firm Dividend Policy. Journal of Financial and Quantitative Analysis, 42(2), 367-398. https://doi.org/10.1017/S0022109000003318

Baskin, J. (1989). An empirical investigation of the pecking order hypothesis. Financial management, 26-35. https://doi.org/10.2307/3665695

Biza-Khupe, S., \& Themba, A., (2016). The relationship between dividend payout and firm financial performance: A study of Botswana listed companies. Archives of Business Research, 4(4), 33-40. https://doi.org/10.14738/abr.44.2163

Brealey, F., Myers, S., \& Allen, F. (2005). Principles of Corporate Finance (8th ed.). Mcgraw-Hill. http://business.ku.ac.ke/images/stories/research/effect_of_dividend_payment.pdf

Chenchene, J., \& Mensah, K. (2015). Dividend policy and its effects on shareholders wealth: Evidence from UK retail industry. International Journal of Liberal Arts and Social Science, 3(2), 52-64.

Chumari, T. (2014). The relationship between dividend payout and financial performance. Unpublished MBA Project, University of Nairobi.

Deeptee, P. \& Roshan, B. (2009). Signaling Power of Dividends on firms future Profits: A Literature Review. Evergreen Energy- Interdisciplinary Journal, 4, 1-9. Available at SSRN: https://ssrn.com/abstract=1359495

Emeni, F. K. \& Ogbulu, O. M. (2015). The Effect of Dividend Policy on the Market Value of Firms in the Financial Services Sector in Nigeria. Archives of Business Research, 3(4), 15-29. https://doi.org/10.14738/abr.34.1253

Friend, I., \& Puckett, M. (1964). Dividends and stock prices. The American Economic Review, 54(5), 656-682. https://doi.org/10.14738/abr.34.1253

Luvembe L., Njangiru, J., \& Mungami, S. (2014). Effect of Dividend Payout on Market Value of Listed Banks in Kenya. International Journal of Innovation Research \& Development, 3(11), 350-370.

Murekefu, T. \& Ouma, O. (2013). The relationship between dividend payout and firm performance: A study of listed companies in Kenya. European Scientific Journal, 8(9), 199-215. http://dx.doi.org/10.19044/esj.2012.v8n9p\%25p

Said Omar, M. \& Echchabi, A. (2019). Dividend Policy and payout practices in Malaysia: A qualitative analysis. Journal of Accounting, Finance and Auditing Studies, 5(1), 226-240. https://doi.org/10.32602/jafas.2019.11

SijolNur, F. \& Abdul B. (2016). Impact of Dividend Policy on Shareholder's Wealth: A study on Manufacturing Industry listed in NASDAQ, America. International Journal of Accounting \& Business Management, 4(2), 251-260. https://doi.org/10.24924/ijabm/2016.11/v4.iss2/251.260

Sindhu, M.I. (2014). Relationship between free cash flow and dividend: Moderating role of firm size. Journal of Finance and Accounting, 5(5), 16-23.

Uwigbe, U., Jafaru, I., \& Ajayi, A. (2012). DIVIDEND POLICY AND FIRMPERFORMANCE: A STUDY OF LISTED FIRMS IN NIGERIA. Accounting and Management Information Systems, 11(3), 442-454.

Wang, G. Y. (2010). The Impacts of free cash flows and Agency costs on firm performance. Journal of service science \& management, 3, 408-418. https://doi.org/10.4236/jssm.2010.34047

\section{Copyrights}

Copyright for this article is retained by the author(s), with first publication rights granted to the journal.

This is an open-access article distributed under the terms and conditions of the Creative Commons Attribution license (http://creativecommons.org/licenses/by/4.0/). 